\title{
Levantamento sorológico e detecção de Salmonella sp.em granjas de postura comercial de pequeno porte em um município do estado do Rio Grande do Sul*
}

\author{
LAURA BEATRIZ RODRIGUES \\ Vladimir Pinheiro do Nascimento (Orientador - UFRGS)
}

Banca: Maristela L. Flores (UFSM), Luciana R. Santos (UPF), Marisa R. I. Cardoso (UFRGS)

Este trabalho teve o intuito de detectar a presença de Salmonella sp. em aves de postura comercial em granjas com pequena produção de um município do Estado do Rio Grande do Sul. Para o isolamento foi utilizado o método microbiológico convencional, com amostragens pelo swab de cloaca e pelo swab de arrasto. Concomitantemente, foi realizada a soroaglutinação rápida em placa (SARP) em todas as aves, com antígenos para Salmonella pullorum e Salmonella enteritidis. O swab de cloaca foi realizado em 360 aves de 6 granjas diferentes, onde também foi executado um $s w a b$ de arrasto. Das granjas analisadas, três delas $(1,3$ e 6$)$ foram negativas para a presença de Salmonella sp. por ambas técnicas. Na granja 2, houve isolamento de S. Ohio em um $s w a b$ de cloaca, sendo que o respectivo lote apresentou resultado negativo pelo $s w a b$ de arrasto. Na granja 4, a $S$. Senftenberg foi detectada em uma ave, e o mesmo sorovar foi isolado por $s w a b$ de arrasto. A granja 5 teve detecção de $S$. Schwarzengrund pelo $s w a b$ de cloaca, e de $S$. Schwarzengrund e $S$. Ohio pelo swab de arrasto. Os resultados demonstrados acima corresponderam a 0,83\% de aves positivas no isolamento em 360 amostras analisadas. A SARP para Salmonella pullorum teve 34 soros positivos em 360 análises, representando 9,44\% do total. Os resultados da SARP com o antígeno para Salmonella Enteritidis tiveram 5,56\% de reações fracas com poucos grumos, consideradas negativas. Finalmente, os resultados finais demonstrados neste experimento permitiram concluir que: $1^{\circ}$ ) a SARP realizada obteve baixa quantidade de soros positivos, de certa forma correspondendo à ausência dos isolamentos destes sorovares; $2^{\circ}$ ) A SARP não deve ser uma técnica utilizada para a confirmação de aves positivas para Salmonella sp. em um lote, mas somente como um teste de triagem; $3^{\circ}$ ) A metodologia de isolamento para o swabs de cloaca e de arrasto permitiu detectar a presença de Salmonella sp. nas amostras coletadas; $4^{\circ}$ ) O status sanitário destas criações de pequeno porte, em relação à pesquisa de Salmonella sp., parece ser muito superior ao que poderia fazer concluir sua baixa tecnificação.

Descritores: Salmonella sp., postura comercial, swabs cloacais e de arrasto, soroaglutinação rápida em placa.

\footnotetext{
* Dissertação de Mestrado n. 333 (Especialidade: Sanidade Avícola). 88f. Programa de Pós-Graduação em Ciências Veterinárias, Faculdade de Veterinária de Porto Alegre - UFRGS. CORRESPONDÊNCIA: L.B. Rodrigues [e-mail: laurab@upf.tche.br].
} 


\title{
Serological study and detection of Salmonella sp. in hensfrom small production laying farms in the state of Rio Grande do Sul (Brazil)**
}

\author{
LAURA BEATRIZ RODRIGUES
}

\author{
Vladimir Pinheiro do Nascimento (Adviser - UFRGS)
}

Committee: Maristela L. Flores (UFSM), Luciana R. Santos (UPF), Marisa R. I. Cardoso (UFRGS)

This study was conducted aiming to detect the presence of Salmonella sp. in hens from small production laying farms from a city in the State of Rio Grande do Sul, Brazil. The conventional microbiological method was used for isolation of the agent from cloacal swab and drag swab samples. At the same time, serum plate agglutination (SPA) was performed in all hens, using coloured antigens of Salmonella Pullorum and Salmonella Enteritidis. The cloacal swab was accomplished in 360 hens of six different farms, where drag swabs were also executed. From the analysed farms, three of them $\left(1^{\text {st }}, 3^{\text {rd }}, 6^{\text {th }}\right)$ were negative in relation to the presence of Salmonella sp. by both techniques. In the second farm $S$. Ohio was isolated in a cloacal swab, while the drag swab resulted negative. In the fourth farm, $S$. Senftenberg was detected in a hen, while the same serovar was isolated by drag swab. Finally, in the fifth farm there was a detection of $S$. Schwarzengrund by cloacal swab and of $S$. Schwarzengrund and $S$. Ohio by the drag swab. The results presented above demonstrated that the agent was isolated in only $0.83 \%$ of the 360 hens sampled. The SPA for Salmonella Pullorum showed 34 positive sera in 360 analysis, representing $9.44 \%$ of the total. The results using the $S$. Enteritidis antigen presented $94.44 \%$ negative samples, while the remained $5.56 \%$ of samples were also considered negative, since they showed weak reactions with few clots. The final results demonstrated in this experiment allowed to conclude that since the SPA test detected only a low number of positive sera it should be only used as a screening test. In relation to the cloacal and drag swabs isolation methodology, it can be concluded that it was able to detect the presence of Salmonella sp. in the collected samples. Finally, the sanitary status of these small production farms, regarding the presence of Salmonella sp., seems to be much better than its poor technology would indicate.

Key words: Salmonella sp., laying hens farms, cloacals and drags swabs, serum plate agglutination.

\footnotetext{
** Master's Thesis no. 333 (Field: Avian Pathology). 88p. Postgraduate Program in Veterinary Sciences, Faculdade de Veterinária de Porto Alegre, Universidade Federal do Rio Grande do Sul (UFRGS) - Brazil. CORRESPONDENCE: L.B. Rodrigues [e-mail: laurab@upf.tche.br].
} 